Article

\title{
How Does Corruption Affect the Adoption of Lobby Registers? A Comparative Analysis
}

\author{
Fabrizio De Francesco ${ }^{1}$ and Philipp Trein ${ }^{2,3, *}$ \\ ${ }^{1}$ School of Government and Public Policy, University of Strathclyde, Glasgow, G42 9RJ, UK; \\ E-Mail: fabrizio.de-francesco@strath.ac.uk \\ 2 Department for Actuarial Sciences, University of Lausanne, 1015 Lausanne, Switzerland; E-Mail: josefphilipp.trein@unil.ch \\ ${ }^{3}$ Institute of Political Studies, Faculty of Social and Political Sciences, University of Lausanne, 1015 Lausanne, Switzerland \\ * Corresponding author
}

Submitted: 14 December 2019 | Accepted: 19 March 2020 | Published: 28 May 2020

\begin{abstract}
Recent research has demonstrated that some governments in developed democracies followed the OECD and the EU recommendations to enhance transparency by adopting lobby registers, whereas other countries refrained from such measures. We contribute to the literature in demonstrating how corruption is linked to the adoption of lobbying regulations. Specifically, we argue that governments regulate lobbying when they face the combination of low to moderate levels of corruption and a relatively well-developed economy. To assess this argument empirically, we compare 42 developed countries between 2000 and 2015, using multivariate logistic regressions and two illustrative case studies. The statistical analysis supports our argument, even if we include a number of control variables, such as the presence of a second parliamentary chamber, the age of democracy, and a spatial lag. The case studies illustrate the link between anti-corruption agenda and the adoption of lobby registers.
\end{abstract}

\section{Keywords}

corruption; interest groups; lobbying; policy diffusion; transparency

\section{Issue}

This article is part of the issue "Fighting Corruption in the Developed World: Dimensions, Patterns, Remedies" edited by Fabrizio Di Mascio (University of Turin, Italy) and Simona Piattoni (University of Trento, Italy).

(C) 2020 by the authors; licensee Cogitatio (Lisbon, Portugal). This article is licensed under a Creative Commons Attribution 4.0 International License (CC BY).

\section{Introduction}

Since the 2000s, more and more countries have adopted lobby registers (Figure 1). These policy changes have happened against the background of the OECD agreement on principles for transparency and integrity in lobbying (OECD, 2010) and the interinstitutional agreement between the European Parliament and the European Commission for a common and voluntary transparency register (European Parliament, 2019; European Parliament \& European Commission, 2014). Prior to these international activities, very few countries have used formal lobby registers (the US in 1946, the Federal Republic of Germany in 1951, Australia in 1983, and Canada in 1989; OECD, 2016).
Scholars have discussed the presence of lobby registers from different angles. On the one hand, researchers have assessed lobby registers as a means of reducing the information asymmetry between legislators and lobbyists and limiting undue interest group influence (Ainsworth, 1993). Further, in this context, lobby registers are a means to level the playing field for politically active interest groups and to avoid a situation where larger groups with more resources have an advantage, as they can better exploit informal lobbying channels (Flavin, 2015). On the other hand, scholars have discussed lobbying regulations in the context of transparency. Researchers have argued that the adoption of lobby register ensures that "citizens have the right to know who is lobbying their government, its officials and 


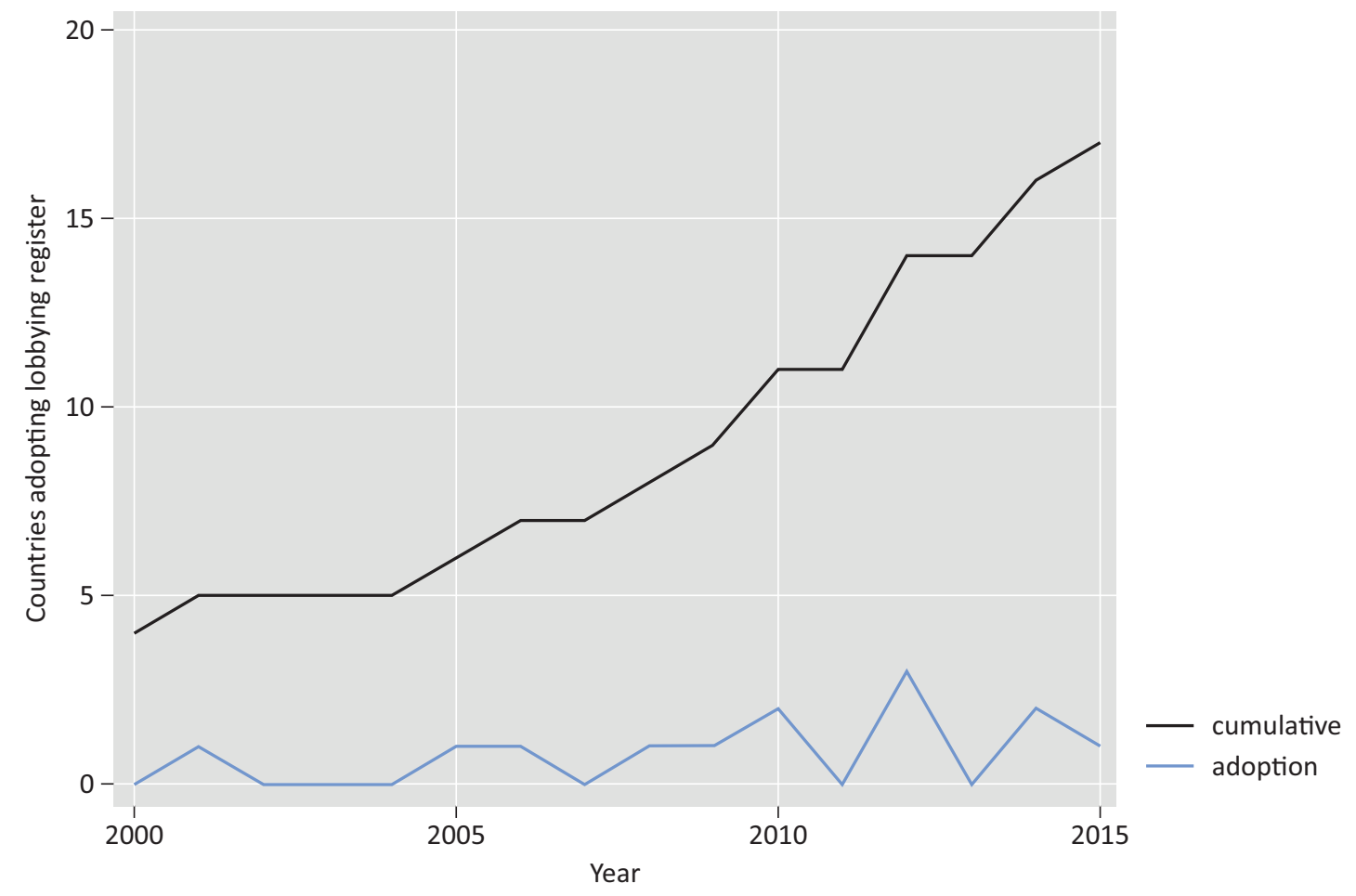

Figure 1. Annual and cumulative frequencies of adoption of lobby register between 2000 and 2015. Note: Lobby registers were adopted in Lithuania (2001), Poland (2005), Hungary (2006), Israel (2008), France (2009), Mexico (2010), Slovenia (2010), Austria (2012), Italy (2012), the Netherlands (2012), Chile (2014), the UK (2014), and Ireland (2015); early adopters not shown. Source: OECD (2016).

officeholders, and what they are lobbying them about" (Murphy, 2017, p. 132). According to this body of literature, the ultimate goal of lobby registers is to reduce and prevent corruption (Bauhr, Czibik, de Fine Licht, \& Fazekas, 2019; Bauhr \& Grimes, 2014, 2017). As a prevention tool, lobby registers allow citizens to monitor and hold accountable elected politicians helping them identify misconduct in the interaction between lobbyists and policymakers (Bunea, 2018; Cini, 2013; Pal, 2012, p. 175).

Although the use of lobby registers has been widely recommended, this international standard (Morais, 2001) has remained in its phase of emergence (Finnemore \& Sikkink, 1998). Researchers have assessed factors that explain differences between various countries' adoption of lobby registers. According to Crepaz (2017), countries that signed the European Transparency Initiative and have a strong second parliamentary chamber have particularly adopted lobby registers. On the contrary, the index of perceived corruption has no impact on the adoption of lobby registers. This result agrees to some extent with the findings of other research, which argues that the presence of systemic corruption successfully hinders the adoption of anti-corruption reforms because if too many individuals profit from corrupt practices, corruption becomes a collective action problem (Persson, Rothstein, \& Teorell, 2013). Another piece of research indicates that in several long-lived democracies statutory lobby registers have been adopted as part of anti-corruption law, such as in France, or pushed through the anti-corruption agenda triggered by political scandals, as in Austria (Bolleyer, 2018).

In this article, we contribute to the literature in demonstrating that low to moderate levels of corruption have a positive effect on the adoption of lobby registers, yet this influence is conditional on the size of the economy. We argue that governments have an incentive to regulate lobbying if they consider that the economic and social benefits from regulating corruption outweigh potential costs. If there is a moderate level of corruption and the economy is developing, policymakers tend to adopt lobby registers as they consider abiding by international anti-corruption standards more important than sustaining existing practices of corruption. On the contrary, very low or high levels of corruption will not result in the adoption of lobbying regulations, either because governments have no reason to act or because too many individuals benefit from corruptive practices.

We support this argument through a quantitative empirical analysis and two case studies. Specifically, we conduct an event history analysis in a sample of 42 developed countries between 2000 and 2015. We control for other explanatory factors, such as the size of interest groups, bicameralism, age of democracy, foreign direct investment, a spatial lag, and time. Further, we present two case studies to discern how the framing of corruption as a political issue, embedded in anti-corruption legislation, leads to the adoption of lobbying regulation. The empirical findings attest that lobby registers are asso- 
ciated with corruption as well as with economic development. Accordingly, this article contributes to this thematic issue on tools for tackling corruption in outlining that the efforts to establish international standards on corruption need to accommodate the differences in the goals, capabilities or actions of individual countries that limit their adherence to international standards.

\section{Corruption, Transparency and the Adoption of Lobby Registers as an International Standard}

\subsection{Lobby Registers, Transparency and Corruption}

The use of registers regulates the access of lobbyists to public officials and decision venues and, consequently, the extent of interest groups' influence on policymaking (Bunea, 2018; Chari, Hogan, \& Murphy, 2012; Greenwood \& Thomas, 1998; Holman \& Luneburg, 2012; OECD, 2009). Lobbyists are required to disclose the intent, beneficiaries, and targets of their activities, and report this key information in a public register (OECD, 2009, p. 28). Therefore, registers inform both public officials and the general public of the extent of lobbying activities (OECD, 2009, p. 28). Whereas public officials rely on this information to understand the electoral salience of a position represented by a lobbyist (Ainsworth, 1993), the public can trace the interaction between lobbyists and policymakers (Bunea, 2018). Thus, lobby registers are an institutional tool that enhances citizens' knowledge of who is influencing policymakers. They allow citizens to observe and scrutinize the interactions between policymakers and private interest groups at the stage of policy formulation (Bunea, 2018). They attempt "to redress the information asymmetry between organized interests and the public," in order "to avoid the risk of biased policy outputs, unequal interest representation/participation, regulatory capture and corruption" (Bunea, 2018, p. 382).

Originally, lobby registers served the purpose of leveling the playing field between and curbing the influence of large interest groups (Flavin, 2015; Zeller, 1948, pp. 239-243). In addition, researchers have pointed out that lobby registers increase transparency by reducing the information asymmetry between citizens and policymakers (Bauhr \& Grimes, 2014, 2017) and by shedding light on the inherently secretive activity of lobbying (Goldberg, 2018). The purpose of this type of transparency is to hold public officials accountable (Bauhr \& Grimes, 2017; OECD, 2009). Being registered and disclosing information determines whether the access of a lobbyist to a policymaker is legitimate (OECD, 2009). The immediate aim of transparency is to make information accessible (Lindstedt \& Naurin, 2010). The ultimatealthough indirect-goals of regulating lobbying are to augment accountability, to prevent corruption (Bauhr et al., 2019; Crepaz \& Chari, 2018; Lindstedt \& Naurin, 2010), and to enhance public trust in political institutions (Chari et al., 2012, p. 5).
The link between lobbying and corruption is important. Since money, relationships, and information are the common ways to influence policymakers (Apollonio, Cain, \& Drutman, 2008), "the modes of influence of lobbying and corruption follow similar patterns and the logic of exchange models with prerequires access and trust" (Goldberg, 2018, p. 201). Accordingly, corruption and lobbying tend to overlap (Campos \& Giovannoni, 2007; Grossman \& Helpman, 2001). Campos and Giovannoni (2007) argue that, in developed countries, lobbying and corruption are interchangeable as lobbyists can influence lawmakers that the resulting rule is aligned to their represented interest, thus making corruption of law enforcers redundant. Further, from a legal perspective it is a complex matter to distinguish between unregulated lobbying and illegal trading in influence that occurs when a person who has real or apparent influence on the decision-making of a public official exchanges this influence for an undue advantage.

\subsection{The Emergence of Lobby Registers as an International Standard}

The anti-corruption aspect on lobby registers has emerged in the policy agenda of the EU (Bunea, 2018, 2019; Cini, 2008, 2013; European Commission, 2007; Kanol, 2012; Milicevic, 2017) and the OECD (Alter, 2010). The OECD recommendations for regulating lobbying, setting ethical conduct, managing conflict of interest, and regulating public procurement all share "a strong moral stance against corruption, bribery, and inappropriate influence in the policy process, as well as support for ethics and integrity in the public service" (Pal, 2012, p. 175). Developed by the Directorate for Public Governance and Territorial Development, the OECD lobbying principles became one of the most influential instruments in setting public governance standards (OECD, 2009, 2012; Pal, 2012, pp. 175-176). In a similar vein, the EU transparency register was part of the European Transparency Initiative that entailed also anti-fraud and financial management, and ethical standards for EU officials (Cini, 2008, p. 750). Like the OECD, the European Commission has promoted and coordinated the EU member states' efforts to ensure transparency through an anti-corruption agenda. In order to share experience on anti-corruption policies, both international organizations (IOs) surveyed their members' lobbying regulation by publishing reports (OECD, 2009, 2012) and collecting data through national anti-corruption reports (European Commission, 2016). An empirical analysis shows that lobbying regulation has emerged as an international standard through processes of socialization (Crepaz, 2017). Nevertheless, in its current stage, the adoption of lobby registers has not yet reached the tipping point of becoming an international norm (Finnemore \& Sikkink, 1998, p. 895). Once enough countries have adopted international standards voluntarily, such standards would evolve into 'hard law, for example through international treaties (Morais, 2001, p. 781) 
or acquire a taken-for-granted quality, in the sense that domestic adherence to international norms is not disputed. In this stage of international norm emergence, the adoption of anti-corruption measures such as lobby registers is the result of the combined effect of external stimuli from IOs' soft governance mechanisms and internal stimuli from domestic political actors (Borz, 2019). In the following, we focus on internal stimuli to explain adoption of lobby registers.

\section{Under Which Conditions Does Corruption Lead to the Adoption of Lobby Registers?}

\subsection{The Conditional Effect of Corruption on Lobbying Regulation}

A comparative empirical analysis of developed democracies has demonstrated that there is no link between corruption and the adoption of lobby registers (Crepaz, 2017). This result fits with the classical view that in rich democracies corruption is not a sufficiently pressing problem to take action (Campos \& Giovannoni, 2007), whereas in poor countries corruption is so endemic that collective action against corruption is impossible (Persson et al., 2013). These results are, however, not satisfactory. In some cases, corruption can contribute to the regulation of lobbying and policymakers will not be able to resist the public demand for enhanced accountability and transparency. For example:

Especially among the wealthier European economies that have been racked by government scandal and public cynicism in recent years, there is a concerted effort by governmental authorities to win back the public's confidence through renewed transparency in the policymaking process. (Holman \& Luneburg, 2012, p. 77)

Against this background, we argue that policymakers will be particularly responsive especially to middle-class citizens' demands to reduce corruption if domestic economic development has resulted in improved working conditions, education and public services (Biswas \& Vijaya, 2019). In these countries, governments want to reduce corruption-at least symbolically-because a high level of perceived corruption tends to stifle economic growth (Mauro, 1995) and causes discontent amongst citizens, especially in middle-income countries and countries with a large and growing middle class (Biswas \& Vijaya, 2019). In this case, policymakers consider it beneficial to regulate lobbying to signal that trading in influence will be prosecuted, and lobbying is a possible legal channel to seek political influence (Campos \& Giovannoni, 2007). This process is particularly likely to happen in EU and OECD member states (OECD, 2009), which have some level of corruption but strive to maintain their economic development and aim at being in good standing with the practices and emerging standards of IOs. In such contexts, citizens and civil society organizations are likely to monitor and sanction the behavior of elected officials and interest groups (Elster, 1998, p. 1) and to promote the adoption of international norms (Borz, 2019), as they aim at maintaining democratic standards and economic prosperity (Biswas \& Vijaya, 2019). Empirically, this mechanism implies that the interaction between the size of the economy and the level of corruption should impact positively on the development of the economy.

\subsection{Additional Domestic Explanations}

One alternative explanation for the adoption of lobby registers is that such measures serve to level the playing field for interest groups, in a context where many large organizations dominate the interest group landscape (Flavin, 2015; Zeller, 1948). To control for this different explanation, we assess whether the structure of civil society-if civil society organizations are composed of larger and smaller organizations-impacts on the probability to adopt lobby registers (Anheier, 2004; Bernhard, 1993). Accordingly, we expect that the presence of larger interest organizations increases the probability of lobby registers adoption as governments would want to make the influence of large interest groups transparent.

Previous empirical models also show that bicameral countries are more likely to adopt lobby registers (Crepaz, 2017). Bicameralism is often more ineffective in ensuring accountability than unicameralism (Testa, 2010) and, consequently, in bicameral countries citizens are more likely to demand anti-corruption tools like lobby registers.

Finally, the age of the democracy could explain the adoption of lobby registers. The older the democratic systems, the less likely it is that policymakers will consider the adoption of such a register to be necessary, as it is likely that there are other institutional practices in place which avoid corruption. However, another way to look at it is that, in an established democracy, the demand for transparency is going to be bigger since transparency is an embedded value in that society and its ability to functions.

\subsection{Economic and External Spatial Factors}

In economies which rely on high level of foreign direct investments, governments are more likely to adopt a lobby register. If foreign investments play an important role, governments have incentives to create lobby registers to ensure transparency standards, which will ensure legal certainty and a level playing field for domestic and foreign investors (Gilardi, 2002).

The spatial dimension is also another potential confounding factor that might explain why governments adopt lobby registers. The more that territorially close countries adopt lobby registers, the more likely a country is to imitate and adopt a lobby register (De Francesco, 2012; Trein, 2017) 


\section{Data, Research Design, and Statistical Model}

In the empirical analysis, we focus on the adoption of lobby registers, rather than measuring the strictness of existing regulations. Our approach follows Ainsworth's (1993) argument that disclosure of key information on lobbyists and interest groups reduces the risk of undue interest group influence. This choice is also justified by the fact that lobbying regulations are afflicted with the definitional issues and problems arising from deciding what distinguishes lobbying from other modes of interest groups representation, and what legitimates lobbying activities (Greenwood \& Thomas, 1998). The extent of robustness of lobbying laws is also contested (Crepaz $\&$ Chari, 2018). This definitional maze is even more evident in a comparative analysis, as in different countries what constitutes legal conduct depends on cultural insights. Further, as lobbying regulations are embedded in broader national anticorruption policies (Doig \& Mclvor, 2003; Piccio, Di Mascio, \& Natalini, 2014), the adoption of lobbying regulations depends on the wider administrative regulatory framework that sets the standards for good governance (OECD, 2009).

To ascertain the year when each country adopted lobby registers, we rely on the OECD's data (OECD, 2016). Like Crepaz (2017), we focus on the probability of a given country adopting a lobby register in a specific year as the dependent variable for our analysis. However, our research design differs in two important ways from Crepaz's (2017) analysis. First, rather than assessing the adoption of registers across 34 developed countries between 1995 and 2014, we analyze the probability of adoption within an extended sample of 42 countries (the OECD partners and member countries and the EU member states), but for a shorter period of time as the first year of observation is 2000 , which is three years before the start of the OECD's engagement with lobbying regulations. This choice is justified by the fact that before 2000 both the EU and the OECD did not engage in promoting lobby registers internationally. Second, due to the limited adoption of lobby registers, we cannot yet explore different mechanisms of policy diffusion, such as emulation, learning, and competition (DiMaggio \& Powell, 1983; Maggetti \& Gilardi, 2016).

Our main independent variables stem from the V-Dem data set (Coppedge et al., 2016). To analyze our main argument, i.e., the interaction of the size of the economy and corruption, we use the ' $v 2 x$ _corr' variable for citizens' perception of corruption. This index provides average values of the following four sub-indexes: i) public sector corruption index; ii) executive corruption index; iii) the indicator for legislative corruption; and iv) the indicator for judicial corruption. To operationalize the size of the economy, we use the World Bank's data on GDP per capita (divided by 10,000 in order for the scale to be convenient for our analysis). We centered the interaction effect around the mean in order to make the interpretation of the results more straightforward (Table 1).

We also use the V-Dem dataset (Coppedge et al., 2016) to operationalize some of the additional explanations. Concerning the size of interest groups, we employ the 'v2csstruc_1' variable from the V-Dem dataset, which measures the extent to which large civil society organizations are highly influential in policymaking. Specifically, this variable is constructed around expert surveys that attempt "to characterize the relative influence of large mass constituency CSOs [civil society organizations] versus smaller, more local, or narrowly construed CSOs" (Coppedge et al., 2016, p. 237). Varying between 0 and 1 , this variable shows the mean of the respondent frequencies and the association of a given country to the fact that large civil society organizations are influential. Accordingly, "the voice of such organizations is recognized by the government and is accorded special weight by policymakers" (Coppedge et al., 2016, pp. 237-238).

Relying on the variables 'v2lgbicam' and 'e_democracy_duration' of the V-Dem dataset, the variable 'bicameralism' is a binary variable that assumes value 1 if a given country has two legislative chambers and the variable 'duration of democracy' measures the years since a given country's transition to democracy, i.e., a political regime that allows electoral contestation

Table 1. Descriptive statistics.

\begin{tabular}{|c|c|c|c|c|c|}
\hline Variable & Obs. & Mean & Std. Dev. & Min. & Max. \\
\hline Adoption of lobby register & 605 & 0.0214876 & 0.145123 & 0 & 1 \\
\hline GDP per capita (USD2010)/10,000 & 672 & 2.770338 & 2.202109 & 0.0698905 & 11.00011 \\
\hline Corruption & 640 & 0.2467482 & 0.2087432 & 0.0093516 & 0.9449248 \\
\hline GDP per capita * Corruption & 640 & 0.3620021 & 0.2911869 & 0.0354769 & 1.637297 \\
\hline Large civil society organizations & 640 & 0.3704611 & 0.267097 & 0 & 1 \\
\hline Bicameralism & 672 & 0.4761905 & 0.4998048 & 0 & 1 \\
\hline Duration of democracy & 672 & 53.7381 & 42.70835 & 1 & 168 \\
\hline Foreign direct investment & 661 & 8.307487 & 31.36755 & -58.97767 & 451.7155 \\
\hline Spatial lag & 630 & 0.0419275 & 0.0455238 & 0 & 0.429576 \\
\hline $\mathrm{t}$ & 672 & 8.5 & 4.613206 & 1 & 16 \\
\hline $\mathrm{t} 2 / 10$ & 672 & 9.35 & 8.067177 & 0.1 & 25.6 \\
\hline $\mathrm{t} 3 / 100$ & 672 & 11.56 & 12.72727 & 0.01 & 40.96 \\
\hline
\end{tabular}


("political leaders that are chosen through free and fair elections") and participation ("a minimal level of suffrage"; Coppedge et al., 2016, p. 321). For all variables from the V-Dem data set, we lagged the observation by three years in order to avoid an endogeneity issue. We used two other data sources for the remaining control variables. The measurement regarding 'foreign direct investment' uses data on trade volume from the World Bank and is lagged by three years. For all variables, except for the age of democracy, we lagged the observation by three years to control for endogeneity. Finally, to create the spatial lag of policy adoption, we followed common standards for the creation of spatial lags in policy diffusion analysis (Gilardi \& Wasserfallen, 2016).

To carry out our empirical analysis, we use Event History Analysis, an established methodology in policy diffusion studies. Amongst the possible Event History Analysis models, we have chosen the logit model, which allows for flexibility in the analysis (Langner, Bender, Lenz-Tönjes, Küchenho, \& Blettner, 2003). In time-series cross-sectional analysis, logit models, however, come with the specification issue related to the likelihood that the observations are temporally dependent (Buckley \& Westerland, 2004; Mooney, 2001). To consider time seriously (Beck, Katz, \& Tucker, 1998), we have inserted three-time variables, ' $\mathrm{t}$,' $\mathrm{t} 2 / 10$,' and ' $\mathrm{t} 3 / 100$,' in the discrete Event History Analysis (Carter \& Signorino, 2010). Finally, we complement the statistical analysis with two case studies, which provide us with more detailed insight on the link between anti-corruption policy agenda and the adoption of lobby registers.

\section{Statistical Results}

To carry out the empirical analysis, we estimated two models, one which examines the main argument of our analysis, testing whether the interaction of corruption and the size of the economy impacts on the adoption of lobbying regulations, and another one that includes the variables for additional explanations (Table 2). The findings suggest that the first model, which includes only the interaction of GDP per capita and corruption fits the data slightly better than the model including the control variables due to a slightly lower Bayesian Information Criterion value.

Substantially, the results indicate that higher corruption rates augment the probability of adopting lobby registers in contexts where the economy is relatively developed. The positive interaction effect suggests that the co-occurrence of corruption and a higher GDP per capita make it more likely that policymakers will adopt a lobby register. If we control for both variables separately, there is no statistically significant effect. In Model 2 of Table 2 we add the control variables. These results indicate that a second parliamentary chamber has a statistically significant effect on the adoption of lobby registers, while the variable 'large civil society organizations' is only marginally significant. All the other control variables do not indicate a statistically significant effect.

To better interpret the findings and to understand their substantial robustness, we now turn to a graphical representation of the results (Figure 2). The lower part of Figure 2 indicates that our sample is composed of several observations characterized by a relatively low level of GDP per capita and high levels of corruption. Another relatively large group of observations is characterized by mid-level of economic development and low-level corruption. To effectively demonstrate the substantial effect of the interaction term, we created a binary variable of the corruption variable, which varies from zero to one at the mean. This strategy allows us to distinguish observations with rather low levels of corruption, represented by

Table 2. Results of the regression analysis (standard errors clustered according to countries).

\begin{tabular}{|c|c|c|c|c|}
\hline & \multicolumn{2}{|c|}{ Model (1) } & \multicolumn{2}{|c|}{ Model (2) } \\
\hline & Coefficients & Standard errors & Coefficients & Standard errors \\
\hline GDP per capita & $-0.490 * *$ & $(0.246)$ & $-1.132 * *$ & $(0.577)$ \\
\hline Corruption & $-7.449 * *$ & $(3.593)$ & $-9.799 * *$ & $(4.123)$ \\
\hline GDP per capita * Corruption & $2.610 * *$ & $(1.179)$ & $4.138 * * *$ & $(1.621)$ \\
\hline Bicameralism & & & $1.600 * *$ & $(0.750)$ \\
\hline Large civil society organizations & & & $1.817^{*}$ & $(1.221)$ \\
\hline Duration of democracy & & & 0.0106 & $(0.0117)$ \\
\hline Foreign direct investment & & & -0.00259 & $(0.00851)$ \\
\hline Spatial lag & & & -8.070 & $(9.341)$ \\
\hline $\mathrm{t}$ & -0.135 & $(0.892)$ & -0.776 & $(1.460)$ \\
\hline $\mathrm{t} 2$ & 0.476 & $(1.085)$ & 1.254 & $(1.732)$ \\
\hline $\mathrm{t} 3$ & -0.200 & $(0.397)$ & -0.452 & $(0.614)$ \\
\hline Constant & -3.038 & $(2.344)$ & -2.279 & $(3.861)$ \\
\hline Pseudo R2 & 0.10 & 0.19 & & \\
\hline Observations & & & & \\
\hline Akaike Information Criterion & & & & \\
\hline Bayesian Information Criterion & & & & \\
\hline
\end{tabular}

Notes: ${ }^{*} \mathrm{p}<0.1 * * \mathrm{p}<0.05^{* * *} \mathrm{p}<0.01$ 


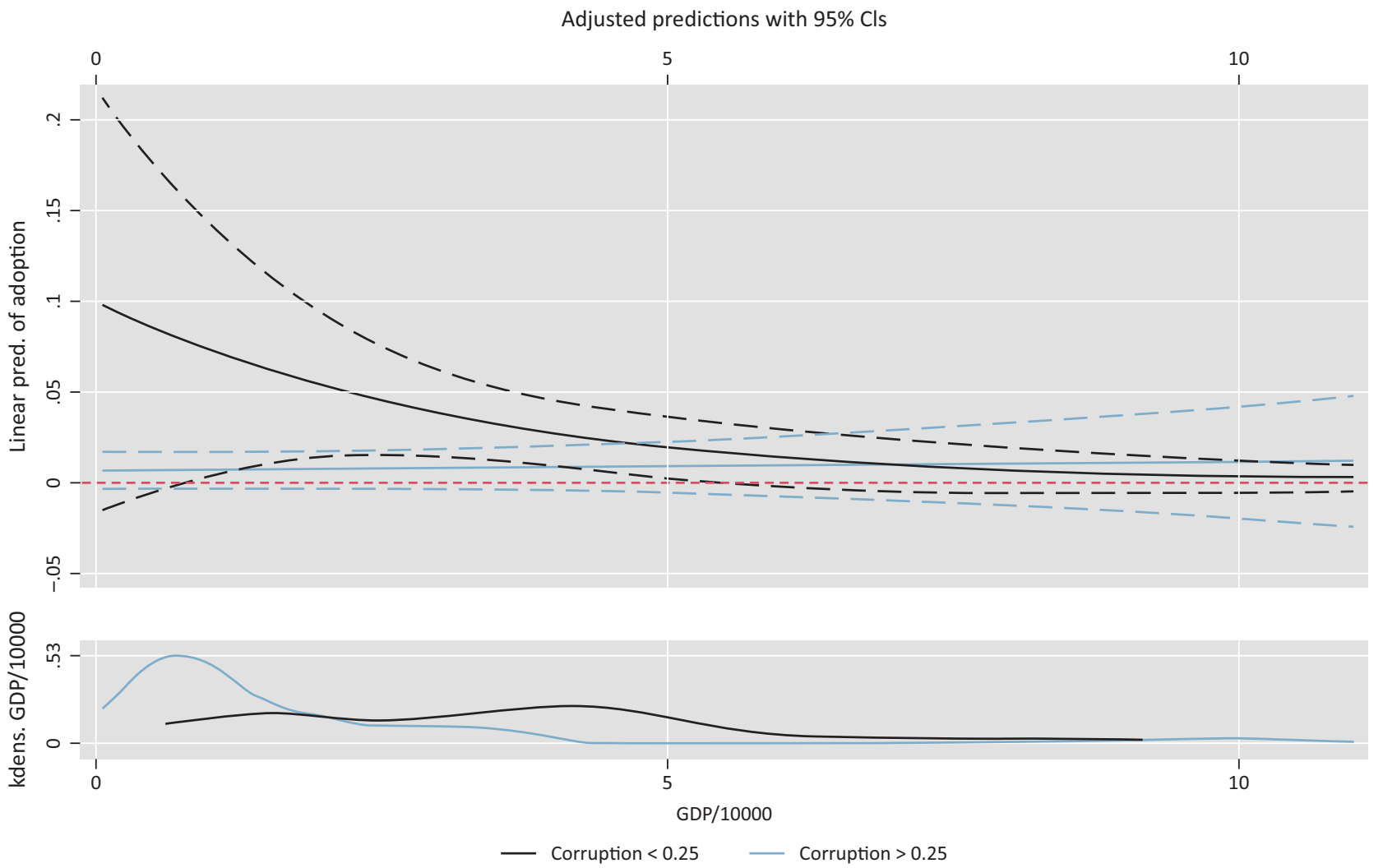

Figure 2. Plot of the interaction effect of GDP per capita and corruption. Source: Authors' own illustration.

the black line in Figure 2, from those with a higher level of corruption, which we identify by the blue line.

The upper part of Figure 2 shows that countries with low levels of corruption and low levels of economic development are most likely to adopt lobby registers, as the black line in the graph is clearly above zero for observations associated with a medium-level GDP per capita. In countries with low levels of corruption and a level of GDP around $\$ 20,000-\$ 40,000$ per capita, policymakers are more likely to adopt lobby registers than in countries with high corruption and low economic development or in countries with high economic development and low corruption.

This finding supports our main argument that under the presence of low to moderate corruption and significant but not very high economic development, policymakers are likely to adopt lobby registers. Such measures signal to citizens that transparency and the reduction of corruption are important goals. Further, these reforms indicate to IOs and companies that the country abides by emerging standards of good governance.

\section{Adopting Lobby Registers in Slovenia and Italy}

In this section, we complement our statistical analyses by tracing the political and institutional process that led Italy and Slovenia to adopt a lobby register, and we illustrate how national lawmakers responded to the external stimulus of the international anti-corruption agenda (Borz, 2019). Both EU countries are characterized by an overall negative public perception of lobbying, reducing the political incentive to pass lobbying regulations (Fink-Hafner, 2017; Habič, 2014; McGrath, 2008; Petrillo, 2017; Transparency International Italia, 2014). First, we focus on Slovenia as it is a 'typical case' (Gerring, 2007) of the relationship that we demonstrate statistically; the values for corruption and GDP per capita are below the mean in the sample. Second, we assess Italy, which is a 'deviant case' (Gerring, 2007) from the above discussed relationship as its corruption levels are clearly above 0.35 and as GDP per capita varies between $\$ 33,000$ and $\$ 38,000$, in the sample. Therefore, the Italian case complements the statistical analysis as it shows how the configuration of relatively high corruption and a developed economy increases the probability of adopting lobby registers.

\subsection{Slovenia}

Slovenia adopted a lobby register in the national anticorruption legislation based on a government bill, after two failed parliamentary initiatives that aimed at passing a specific law on lobbying and public participation in lawmaking process (Habič, 2014, p. 14; Kosmač, 2014). The 2010 Integrity and Prevention of Corruption Act established one of the most comprehensive sets of lobbying regulations in Europe (Holman \& Luneburg, 2012). The lobby register was adopted in the wake of an increase in the influence of interest groups on policymaking, which prompted public concern about corruption. Within this 
anti-corruption framework, the register aims to tackle the secrecy in the relationship between professional lobbyists and public officials that is often associated with bribery in Slovenia (Habič, 2014, p. 15). Accordingly, the 2010 Integrity and Prevention of Corruption Act targets both lobbyists and legislative and executive public officials at the national and local level (Kosmač, 2014). On the one hand, as employees or legal representative are excluded from the legislation, only professional lobbyists are required to register with the Commission for Prevention of Corruption, the national anti-corruption agency, and to summarize annually their activity details; on the other hand, public officials have to check that lobbyists contacting them are registered and report to the Commission for Prevention of Corruption on each meeting. The Commission for Prevention of Corruption is in charge of enforcing the regulations and has power to sanction non-compliance (Group of States against Corruption, 2018; Habič, 2014; Mulcahy, 2015).

The influence of the EU and the OECD was important for shifting lobbying regulation onto the anti-corruption agenda after the failure of the National Assembly to regulate lobbying (Habič, 2014, p. 14; Kosmač, 2014). Through the 2010 Integrity and Prevention of Corruption Act, Slovenia complied with international obligations on preventing and combating corruption, which proves this point. In 2002, the international anti-corruption standards facilitated the emergence of the anti-corruption policy through the institutionalization of the Office of the Government for the Prevention of Corruption. Two years later, the policy was consolidated through the adoption of the Prevention of Corruption Act, which transformed the Office of the Government for the Prevention of Corruption into an independent body accountable to the Parliament. It is important to note that the main result of the Office of the Government for the Prevention of Corruption was the 2002 legislative draft to prevent corruption that was the basis for the 2004 Prevention of Corruption Act (Dobovšek \& Škrbec, 2012, p. 167), which specified compliance with anti-corruption conventions and international standards (Dobovšek \& Škrbec, 2012, p. 173). These legislative and institutional conditions were the bedrock of a further expansion of anticorruption policy. Overall, the institutional alignment of the Slovenian anti-corruption policy with international standards facilitated the adoption of the lobby register notwithstanding the inconsistent political support for the policy (Dobovšek \& Škrbec, 2012, p. 177).

\subsection{Italy}

Despite the OECD's assessment that Italy adopted a comprehensive lobby register, the regulatory landscape in the country is fragmented. Comprehensive national legislation has not been adopted, despite numerous parliamentary and executive initiatives starting in the mid1970s (Chamber of Deputies, 2016). In 2012, the Ministry of agriculture adopted a public list of lobbyists en- gaged within agribusiness (Chamber of Deputies, 2016). The Ministry of Economic Development, the Ministry of Labor and Social Policy, and the Ministry of Environment followed later. At the local level, six regions (Tuscany in 2002, Molise in 2004, Abruzzo in 2010, Calabria in 2016, Lombardy in 2016, and Apulia in 2017) also adopted lobby registers (Carloni, 2017). By establishing a consultation procedure for new regulatory proposals (Transparency International Italia, 2014, p. 9), the Ministry of agriculture was the first Italian institution to specify the rights and obligations associated with the activities of interest groups in the policymaking process at the national level. Further, in 2016, the Chamber of Deputies internally regulated lobbying activities through a register maintained by the Office of the President. Notwithstanding the lack of national legislation on lobbying, the enactment of these two registers was a sufficient condition for being considered by the OECD as a country that has adopted a lobby register (OECD, 2016).

The fragmentation of the Italian lobbying regulations and anti-corruption legislation is a sort of functional equivalent of a uniform and comprehensive lobby register. Indeed, the adoption of lobby registers by several different national and regional institutions has filled the gap left by the 2012 anticorruption law that targets civil servants rather than elected officials. Contrary to Slovenia's uniform and comprehensive lobbying regulation, the Italian anti-corruption legislation assembles a series of measures for enhancing administrative transparency and integrity (e.g., regulation of public officials' conflict of interests and transparency of public administration through proactive disclosure of information). However, by combining the regulation of conflict of interests and administrative transparency, the Italian anticorruption legislation contains several elements for 'indirectly' regulating interest groups' influence on executive and administrative policymaking (cf. Carloni, 2017). Through a sequence of sectoral adoptions and the cumulative effect of measures for tackling administrative corruption, the Italian case is a one of consolidation of lobbying regulation that is often misjudged by the assessment of the European Commission and the OECD.

The Italian approach follows an established logic of the country's postwar consolidation of democracy (Morlino, 1998), according to which parties have low incentives to regulate their interaction with civil society and governments (Pasquino, 1989). This mechanism is visible in the process of lobbying regulation. For example, the above-mentioned lobby registers and code of conduct were considered as necessary instruments for enhancing the 'political ethics' by a group of experts on institutional reforms appointed by the President of Republic, Giorgio Napolitano (Mauro, Onida, Quagliariello, \& Violante, 2013). Further, the adoption of the lobby register within the Ministry of Agriculture passed under the technocratic government of Mario Monti. In the same year, that government was crucial for the adoption of anti-corruption law and the establish- 
ment of an anti-corruption agency, as the parliamentary approval was obtained through a confidence vote. This law aligned Italy with international norms on public administrators' transparency, integrity, and incompatibility (Piccio et al., 2014).

The Italian resistance against comprehensive legislation on the matter is linked to the perception that lobbying should not be 'legalized' as a professional form of interest group representation. According to this logic, professional lobbyists (and more in general interest groups) are detrimental to the traditional but declining forms of representation such as political parties (Carloni, 2017; Petrillo, 2017) and corporative institutions (Pritoni, 2019). This aversion of the Italian legislators to lobbying is also evident in its definitions that encompass any type of interest group engaged in indirect or direct forms of political influence. As opposed to Slovenia, where public relations have a long tradition (Fink-Hafner, 2017), this may be also due to the lack of recognized training and professionalization of Italian lobbyists (Petrillo, 2017). Further, the polarization of the anti-corruption agenda has not facilitated the formation of reform coalitions (Della Porta \& Vannucci, 2007; Di Mascio, Maggetti, \& Natalini, 2018), nor has there been a steady institutionalization of the anti-corruption policy (Piccio et al., 2014) as in Slovenia. The Italian lawmakers' line of resistance to international pressure was weakened only in occasion of technocratic governments and the 2013 electoral success of a new party, the Five Star Movement (Piccio et al., 2014). These unorthodox agents of reform were able to overcome the impossibility of forming reform coalitions "given the greater inflexibility of the administrative bureaucracies and the higher degree of conflict among the government parties" that distinguishes the Italian political system from other economically developed democracies (Pasquino, 1989, pp. 37-38).

\section{Discussion and Conclusions}

This article has analyzed the adoption of lobby registers across 42 countries. Starting with the assumption that the OECD and the EU have been influencing the adoption of lobby registers (Crepaz, 2017), our research question has focused on corruption as the main rationale for countries to respond to the emergence of an international norm characterized by an anti-corruption agenda. By reducing the information asymmetry between citizens and elected officials, registers enhance transparency in lobbying activities, with the potential to reduce the likelihood of biased and undue influence, and ultimately of corrupt policymaking (Bolleyer, 2018).

Our statistical findings show that the interaction between the size of the economy and corruption explains why governments adopt lobby registers. Most of the countries that have adopted lobby registers are not characterized by high levels of corruption and high levels of economic development. Instead, among our sample of 42 of the most developed countries, the adoption of lobby registers is mainly associated with low to moderate corruption and a significant but not very high GDP per capita. Our explanation for this pattern is that politicians have an incentive to regulate lobbying if they want to push economic development forward and respond to middle class demand to reduce corruption. This finding fits with other research on corruption, which indicates that in middle-income countries citizens are most concerned about corruption (Biswas \& Vijaya, 2019). Specifically, the legalization of professional lobbying creates certainty for corporations and increases the attractiveness of a country for foreign investors.

The two case studies show that both in Italy and in Slovenia lobby registers were adopted through an anticorruption agenda as promoted by IOs. The two countries differ in terms of underlying conditions for the adoption and implementation of a lobby register. While in Slovenia the lobby register was adopted through an incremental institutionalization of international standards policy, in Italy political resistance to the idea of recognizing (professional) lobbying was removed only during two windows of opportunity that opened up in 2012 and 2016 , resulting in a fragmented set of registers adopted and maintained by few national and regional institutions. Nevertheless, their embeddedness in a multilevel context (Thomann, Trein, \& Maggetti, 2019; Trein, Thomann, \& Maggetti, 2019) contributed to the adoption of lobby registers for both countries.

Although our results provide an interesting explanation for the adoption of lobby registers, there are limitations to our analysis. The diffusion process regarding lobby registers is still underway; within the next 10 years many more countries will perhaps have adopted such registers, making them a consolidated norm, and accordingly internal functional explanations might not play a role. Conversely, governments could opt to adopt other transparency mechanisms and anticorruption tools enabling control of bureaucracy rather than interest groups and elected officials. Furthermore, lobbying regulations were often discarded thanks to their complexity (Crepaz \& Chari, 2018) and their record of limited effectiveness in corrupt settings (dos Santos \& da Costa, 2014), leading to citizens' resigned acceptance rather than indignation (Bauhr \& Grimes, 2014).

However, focusing on the initial wave of adoption of a public governance standard, this empirical analysis allows us to make practical recommendations to IOs engaged in the provision of international best practices for policymaking transparency. Although IOs have correctly associated lobby registers with the issue of corruption, it is important to note that the promotion of this institutional solution may lead to symbolic adoption. To avoid such risk, IOs should also frame lobbying regulation as a way to enhance the profession of public relations and lobbyists, as the case of Slovenia attests. A more comprehensive agenda framed around the conditions for ensuring more professional lobbying could transform the negative public perception of lobbying as a tool for channeling 
interest group positions, and, ultimately, achieving policy responsiveness to the general public.

\section{Acknowledgments}

We wish to thank the two anonymous reviewers and the Academic Editors of this thematic issue for providing constructive comments on earlier versions of this article. We also thank Maria Zuffova for data collection, and Jacqueline Young for language editing. Fabrizio De Francesco acknowledges the funding support of the FP7 People: Marie-Curie Actions [GIAmRule; PCIG12-GA2012-334008].

\section{Conflict of Interests}

The authors declare no conflict of interests.

\section{Supplementary Material}

Supplementary material (data set and replication code) for this article is available online in the format provided by the author (unedited). A copy of this material is also available at the University of Strathclyde KnowledgeBase at https://doi.org/10.15129/3b59f78c-7d12-4740b50d-7cbf37f61d92

\section{References}

Ainsworth, S. (1993). Regulating lobbyists and interest group influence. The Journal of Politics, 55(1), 41-56.

Alter, R. (2010). Clearer lobbying for cleaner policymaking: The OECD has developed new guidelines to help make lobbying more transparent and even-handed. OECD Observer, 279, 61-63.

Anheier, H. (2004). Civil society: Measurement, evaluation, policy. London and Sterling: Earthscan.

Apollonio, D., Cain, B. E., \& Drutman, L. (2008). Access and lobbying: Looking beyond the corruption paradigm. Hastings Constitutional Law Quarterly, 36(1), 13-50.

Bauhr, M., Czibik, Á., de Fine Licht, J., \& Fazekas, M. (2019). Lights on the shadows of public procurement: Transparency as an antidote to corruption. Governance. https://doi.org/10.1111/gove.12432

Bauhr, M., \& Grimes, M. (2014). Indignation or resignation: The implications of transparency for societal accountability. Governance, 27(2), 291-320.

Bauhr, M., \& Grimes, M. (2017). Transparency to curb corruption? Concepts, measures and empirical merit. Crime, Law and Social Change, 68(4), 431-458.

Beck, N., Katz, J. N., \& Tucker, R. (1998). Taking time seriously: Time-series-cross-section analysis with a binary dependent variable. American Journal of Political Science, 42(2), 1260-1288.

Bernhard, M. (1993). Civil society and democratic transition in East Central Europe. Political Science Quarterly, 108(2), 307-326.
Biswas, B., \& Vijaya, R. M. (2019). Who protests? An exploration of the class dimensions of anticorruption mobilization. Governance, 32(4), 639-655.

Bolleyer, N. (2018). The state and civil society: Regulating interest groups, parties, and public benefit organizations in contemporary democracies. Oxford: Oxford University Press.

Borz, G. (2019). Combating corruption in Europe: A stimulus-response approach. European Political Science, 18(2), 217-233.

Buckley, J., \& Westerland, C. (2004). Duration standard errors: Improving EHA models of state policy diffusion. State Politics \& Policy Quarterly, 4(1), 94-113.

Bunea, A. (2018). Legitimacy through targeted transparency? Regulatory effectiveness and sustainability of lobbying regulation in the European Union. European Journal of Political Research, 57(2), 378-403.

Bunea, A. (2019). Regulating European Union lobbying: In whose interest? Journal of European Public Policy, 26(11), 1579-1599.

Campos, N. F., \& Giovannoni, F. (2007). Lobbying, corruption and political influence. Public Choice, 131(1), $1-21$.

Carloni, E. (2017). Regolazione del lobbying e politiche anticorruzione [Lobbying regulation and anticorruption policies. Rivista Trimestrale di Diritto Pubblico, 2, 371-411.

Carter, D. B., \& Signorino, C. S. (2010). Back to the future: Modelling time dependence in binary data. Political Analysis, 18(3), 271-292.

Chamber of Deputies. (2016). Regolamentazione dell'attività di rappresentanza di interessi nelle sedi della Camera dei deputati [Regulation of interest representation activities within the Chamber of deputies]. Rome: Chamber of Deputies.

Chari, R., Hogan, J., \& Murphy, G. (2012). Regulating lobbying: A global comparison. Manchester: Manchester University Press.

Cini, M. (2008). European Commission reform and the origins of the European Transparency Initiative. Journal of European Public Policy, 15(5), 743-760.

Cini, M. (2013). EU decision-making on inter-institutional agreements: Defining (common) rules of conduct for European lobbyists and public servants. West European Politics, 36(6), 1143-1158.

Coppedge, M., Gerring, J., Lindberg, S. I., Skaaning, S.-E., Teorell, J., Altman, D., . . . Zimmerman, B. (2016). V-Dem codebook v6. Gothenburg: Varieties of Democracy (V-Dem) Project. Retrieved from https:// www.v-dem.net/en/reference/version-6-mar-2016

Crepaz, M. (2017). Why do we have lobbying rules? Investigating the introduction of lobbying laws in EU and OECD member states. Interest Groups \& Advocacy, 6(3), 231-252.

Crepaz, M., \& Chari, R. (2018). Assessing the validity and reliability of measurements when evaluating public policy. Journal of Public Policy, 38(3), 275-304.

De Francesco, F. (2012). Diffusion of regulatory impact 
analysis among OECD and EU member states. Comparative Political Studies, 45(10), 1277-1305.

Della Porta, D., \& Vannucci, A. (2007). Corruption and anti-corruption: The political defeat of 'Clean Hands' in Italy. West European Politics, 30(4), 830-853.

Di Mascio, F., Maggetti, M., \& Natalini, A. (2018). Exploring the dynamics of delegation over time: Insights from Italian anti-corruption agencies (2003-2016). Policy Studies Journal. https://doi.org/10.1111/psj. 12253

DiMaggio, P. J., \& Powell, W. W. (1983). The iron cage revisited: Institutional isomorphism and collective rationality in organizational fields. American Sociological Review, 48(2), 147-160.

Dobovšek, B., \& Škrbec, J. (2012). Corruption prevention model in the Republic of Slovenia. Cahiers Politiestudies, 24, 165-180.

Doig, A., \& Mclvor, S. (2003). The national integrity system: Assessing corruption and reform. Public Administration and Development, 23(4), 317-332.

dos Santos, L. A., \& da Costa, P. M. T. (2014). The contribution of lobby regulation initiatives in addressing political corruption in Latin America. Journal of Public Affairs, 14(3/4), 379-391.

Elster, J. (1998). Deliberative democracy. Cambridge: Cambridge University Press.

European Commission. (2007). Communication from the Commission to the European Parliament, the European Economic and Social Committee and the Committee of the Regions: A single market for 21st century Europe. Brussels: European Commission. Retrieved from http://eur-lex.europa.eu/LexUriServ/ site/en/com/2007/com2007_0724en01.pdf

European Commission. (2016). Anti-corruption report. Brussels: European Commission. Retrieved from https://ec.europa.eu/home-affairs/what-we-do/ policies/organized-crime-and-human-trafficking/ corruption/anti-corruption-report_en

European Parliament. (2019). Legislative train schedule union of democratic change: Interinstitutional agreement on a mandatory transparency register for lobbyist. Brussels: European Parliament. Retrieved from http://www.europarl.europa.eu/legislativetrain/theme-union-of-democratic-change/fileinter-institutional-agreement-on-a-mandatorytransparency-register-for-lobbyists

European Parliament, \& European Commission. (2014). Interinstitutional agreement between the European Parliament and the European Commission on the transparency register for organisations and selfemployed individuals engaged in EU policy-making and policy implementation. Brussels: European Parliament and European Commission.

Fink-Hafner, D. (2017). Slovenia. In A. Bitonti \& P. Harris (Eds.), Lobbying in Europe (pp. 299-311). London: Palgrave Macmillan.

Finnemore, M., \& Sikkink, K. (1998). International norm dynamics and political change. International Organi- zation, 52(4), 887-917.

Flavin, P. (2015). Lobbying regulations and political equality in the American states. American Politics Research, 43(2), 304-326.

Gerring, J. (2007). Case study research: Principles and practice. New York, NY: Cambridge University Press.

Gilardi, F. (2002). Policy credibility and delegation to independent regulatory agencies: A comparative empirical analysis. Journal of European Public Policy, 9(6), 873-893.

Gilardi, F., \& Wasserfallen, F. (2016). How socialization attenuates tax competition. British Journal of Political Science, 46(1), 45-65.

Goldberg, F. (2018). Corruption and lobbying: Conceptual differentiation and gray areas. Crime, Law and Social Change, 70(2), 197-215.

Greenwood, J., \& Thomas, C. S. (1998). Introduction: Regulating lobbying in the Western world. Parliamentary Affairs, 51(4), 487-499.

Grossman, G. M., \& Helpman, E. (2001). Special interest politics. Cambridge, MA: MIT Press.

Group of States against Corruption. (2018). Fifth evaluation round (Evaluation Report: Slovenia). Strasbourg: Council of Europe.

Habič, S. (2014). Lifting the lid on lobbying, Slovenia: Call for transparent and ethical lobbying. Ljubljana: Transparency International Slovenia.

Holman, C., \& Luneburg, W. (2012). Lobbying and transparency: A comparative analysis of regulatory reform. Interest Groups \& Advocacy, 1(1), 75-104.

Kanol, D. (2012). Should the European Commission enact a mandatory lobby register? Journal of Contemporary European Research, 8(4), 519-529.

Kosmač, J. (2014). Slovenia: The regulation of lobbying in place and the challenge of implementation. In OECD (Ed.), Lobbyists, governments and public trust (pp. 206-214). Paris: OECD Publishing.

Langner, I., Bender, R., Lenz-Tönjes, R., Küchenho, H., \& Blettner, M. (2003). Bias of maximum-likelihood estimates in logistic and cox regression models: A comparative simulation study (Discussion Paper No. 362). Bonn: Collaborative Research Center. Retrieved from www.econstor.eu/dspace/bitstream/ 10419/31093/1/481668578.pdf

Lindstedt, C., \& Naurin, D. (2010). Transparency is not enough: Making transparency effective in reducing corruption. International Political Science Review, 31(3), 301-322.

Maggetti, M., \& Gilardi, F. (2016). Problems (and solutions) in the measurement of policy diffusion mechanisms. Journal of Public Policy, 36(1), 87-107.

Mauro, M., Onida, V., Quagliariello, G., \& Violante, L. (2013). Final report of working group on institutional reform. Rome: Working Group on Institutional Reform. Retrieved from http://www.giurcost. org/cronache/relazioneriforme.pdf

Mauro, P. (1995). Corruption and growth. The Quarterly Journal of Economics, 110(3), 681-712. 
McGrath, C. (2008). The development and regulation of lobbying in the new member states of the European Union. Journal of Public Affairs: An International Journal, 8(1/2), 15-32.

Milicevic, A. (2017). The mandatory transparency register initiative: Towards a better governance of lobbying in the EU. Review of European Law, 19(1), 71-114.

Mooney, C. Z. (2001). Modeling regional effects on state policy diffusion. Political Research Quarterly, 54(1), 103-124.

Morais, H. V. (2001). The quest for international standards: Global governance vs. sovereignty. University of Kansas Law Review, 50(4), 779-822.

Morlino, L. (1998). Democracy between consolidation and crisis: Parties, groups, and citizens in Southern Europe. Oxford: Oxford University Press.

Mulcahy, S. (2015). Lobbying in Europe: Hidden influence, privileged access. Berlin: Transparency International.

Murphy, G. (2017). Lobbying regulation in Ireland: Fool's errand or finest hour? Administration, 65(2), 127-144.

Organisation for Economic Co-operation and Development. (2009). Lobbyists, governments and public trust (Vol. 1). Paris: OECD Publishing. Retrieved from http://www.oecd-ilibrary.org/content/book/ 9789264073371-en

Organisation for Economic Co-operation and Development. (2010). Recommendation of the Council on principles for transparency and integrity in lobbying (OECD/LEGAL/0379). Paris: OECD.

Organisation for Economic Co-operation and Development. (2012). Lobbyists, governments and public trust (Vol. 2). Paris: OECD Publishing.

Organisation for Economic Co-operation and Development. (2016). OECD lobbying timeline. Retrieved from http://www.oecd.org/corruption/ethics/ lobbying.htm

Pal, L. A. (2012). Frontiers of governance: The OECD and global public management reform. Basingstoke: Palgrave Macmillan.

Pasquino, G. (1989). Unregulated regulators: Parties and party government. In P. Lange \& M. Regini (Eds.),
State, market and social regulation: New perspectives on Italy (pp. 29-50). Cambridge: Cambridge University Press.

Persson, A., Rothstein, B., \& Teorell, J. (2013). Why anticorruption reforms fail: Systemic corruption as a collective action problem. Governance, 26(3), 449-471.

Petrillo, P. L. (2017). Italy. In A. Bitonti \& P. Harris (Eds.), Lobbying in Europe: Public affairs and the lobbying industry in 28 EU Countries (pp. 207-218). London: Palgrave Macmillan.

Piccio, D., Di Mascio, F., \& Natalini, A. (2014). Tackling corruption finally? How domestic and supranational factors have led to incremental policy change in Italy. In J. Mendilow \& I. Peleg (Eds.), Corruption in the contemporary world (pp. 173-196). Lanham, MD: Lexington Books.

Pritoni, A. (2019). Exploring the impact of partisan gatekeeping on interest group representation and bias: The case of Italy (1987-2015). Interest Groups \& Advocacy, 8(1), 68-90.

Testa, C. (2010). Bicameralism and corruption. European Economic Review, 54(2), 181-198.

Thomann, E., Trein, P., \& Maggetti, M. (2019). What's the problem? Multilevel governance and problem-solving. European Policy Analysis, 5(1), 37-57.

Transparency International Italia. (2014). Lobbying $e$ Democrazia. La rappresentanza degli interessi in Italia [Lobbying and Democracy. The representation of interests in Italy]. Retrieved from https:// www.transparency.it/wp-content/uploads/2014/11/ LobbyingDemocrazia_Transparency_International_ Italia_cor.pdf

Trein, P. (2017). Europeanisation beyond the European Union: Tobacco advertisement restrictions in Swiss cantons. Journal of Public Policy, 37(2), 113-143.

Trein, P., Thomann, E., \& Maggetti, M. (2019). Integration, functional differentiation and problem-solving in multilevel governance. Public Administration, 97(2), 339-354.

Zeller, B. (1948). The federal regulation of lobbying act. American Political Science Review, 42(2), 239-271.

\section{About the Authors}

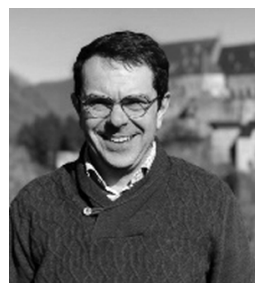

Fabrizio De Francesco is a Senior Lecturer in Public Policy at the School of Government and Public Policy, University of Strathclyde, Glasgow. He has been a Visiting Researcher at the University of Heidelberg, University of Lausanne, and University of Leiden. His research on regulatory institutions, the diffusion of administrative reform, and transnational governance has been published in Comparative Political Studies, Journal of European Public Policy, Public Administration, and SocioEconomic Review.

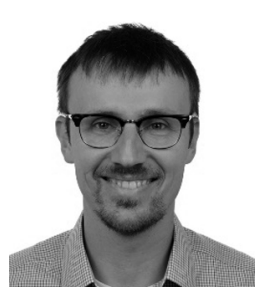

Philipp Trein is a Senior Researcher at the University of Lausanne, Switzerland, and a Senior Fellow at the Institute of European Studies at the University of California, Berkeley. His research focuses on comparative public policy, policy learning, federalism, and political economy. His book Healthy or Sick? Coevolution of Health Care and Public Health in a Comparative Perspective was published by Cambridge University Press in 2018. More information on his research is available at https://www.philipptrein.com 